\title{
Analysis of Application Based on Cloud Computing in Banking Industries in Indonesia Using Technology Acceptance Model (TAM) 2 Method Case Study The National Private Banks in Surabaya and Bali Region
}

\author{
I Wayan Jatu Wira Purnama ${ }^{1}$ and Raden Venantius Hari Ginardi ${ }^{1}$
}

\begin{abstract}
Cloud computing applications remain rarely used in the banking industry in Indonesia. $X$ is one of the national private banks in Indonesia, which is the first bank to use cloud computing application in their operations. Since it is the first bank to use such technology, the the researcher aims to measure the acceptance and ease of use of cloud computingbased applications, and to measure the level of user satisfaction with the TAM 2 method (Technology Acceptance Model 2). The researcher used the TAM 2 method because it is the development of the TAM 1 method which adds social influence and external perspective variables. Variables in TAM 2 are subjective norms, image, result demonstrability, job relevance, voluntariness, perceived usefulness, perceived ease of use, intention to use and usage behavior. Distribution of questionnaire samples was conducted to 90 respondents in Surabaya and Bali. Data from the questionnaire were tested in terms of validity and reliability, correlation and regression, variable descriptive analysis, and hypothesis. From the results, it was found that the twelve hypotheses in TAM 2 were all acceptable and the most significant effect was the outcome quality variable towards the benefits of using cloud computing applications at $41.2 \%$. Therefore, it can be concluded that the greater the quality of the result of cloud computing applications, the greater the benefits of the technology.
\end{abstract}

Keywords-Cloud computing, TAM 2, Banking Industry.

\section{INTRODUCTION}

Customer trust is an important capital in maintaining the reputation of a bank, so that customer service is a significantly important business in the banking industry. At present, the speed of providing quality customer service is a must for banks in order to compete and thrive. Every bank currently strives to provide a mobile service, so that customers can transact wherever and whenever; in this case, technology is the answer in order to compete in the future.

\footnotetext{
${ }^{1}$ I Wayan Jatu Wira Purnama and Raden Venantius Hari Ginardi are with Departement of Business and Management Technology, Institut Technology Sepuluh Nopember, Surabaya, Indonesia. E- mail: wayan.1902@mhs.its.ac.id; hariginardi@gmail.com.
}

The use of cloud computing technology began to be adopted in one of the national private banks to answer the challenge. All employees at the national private bank from the board of directors to the staff level use cloud computing-based applications for their daily work. Cloud computing is a combination of the use of computer technology and internet-based development (cloud) [1]. The advantage of cloud computing is the ease of accessing software or data stored on the internet so that users do not have to use the same computer to access software [2].

Business people and staff who work mobile find it hard to monitor the work progress of their employee or other colleagues. Moreover, Office and communication software is their daily business tool. Thus, a system accessible everywhere and every time to facilitate their work is needed. Since it is newly implemented in the banking industry without any prior measurement, the researcher aims to measure and test the practicality of cloud computing based applications, to measure the acceptance and ease of use of cloud computing-based applications, and to measure the level of user satisfaction using the TAM (Technology Acceptance Model) method.

TAM (Technology Acceptance Model) is one of the research models used to predict the adoption of information technology [3]. Using the TAM (Technology Acceptance Model) method, the assumption is that when users implement a new information system, there are two factors that influence, namely the Ease of Use Perceived and Usefulness Perceived [4]. TAM (Technology Acceptance Model) conceptualizes how users receive and use new technologies [5]. It comes from a psychological theory approach to explain users which refer to the beliefs, attitudes, interests, and relationships of user behavior. TAM (Technology Acceptance Model) has 3 different construct models, TAM 2 contains eleven (11) constructs [6].

TAM 2 method (Technology Acceptance Model) was chosen because the variables are considered to be more sufficient to answer the formulated research problem in 
measuring cloud computing-based applications in one of the national private banks, that this method is sufficiently complex to support solutions, and is the most widely used model in the adoption and use of information technology that has proven to be predictive in the adoption and use of information technology. Also, the TAM method is the model that is considered to be the most suitable model in explaining how users receive a system.

This measurement aims to help model and predict the level of user acceptance, so that a corrective step can be designed to increase the level of acceptance of cloud computing-based application services in building an advanced banking industry.

The result of this study is to find out variables that have a significant effect on other variables in TAM 2. Also, it would be found through the result that the regression test of all hypotheses from the TAM 2 method are all acceptable. The most significant variable with the greatest value is the output quality variable with the perceived usefulness variable of $41.2 \%$, while the variable that has the most significant effect on the smallest value is the perceived ease of use with perceived usefulness of $4.9 \%$.

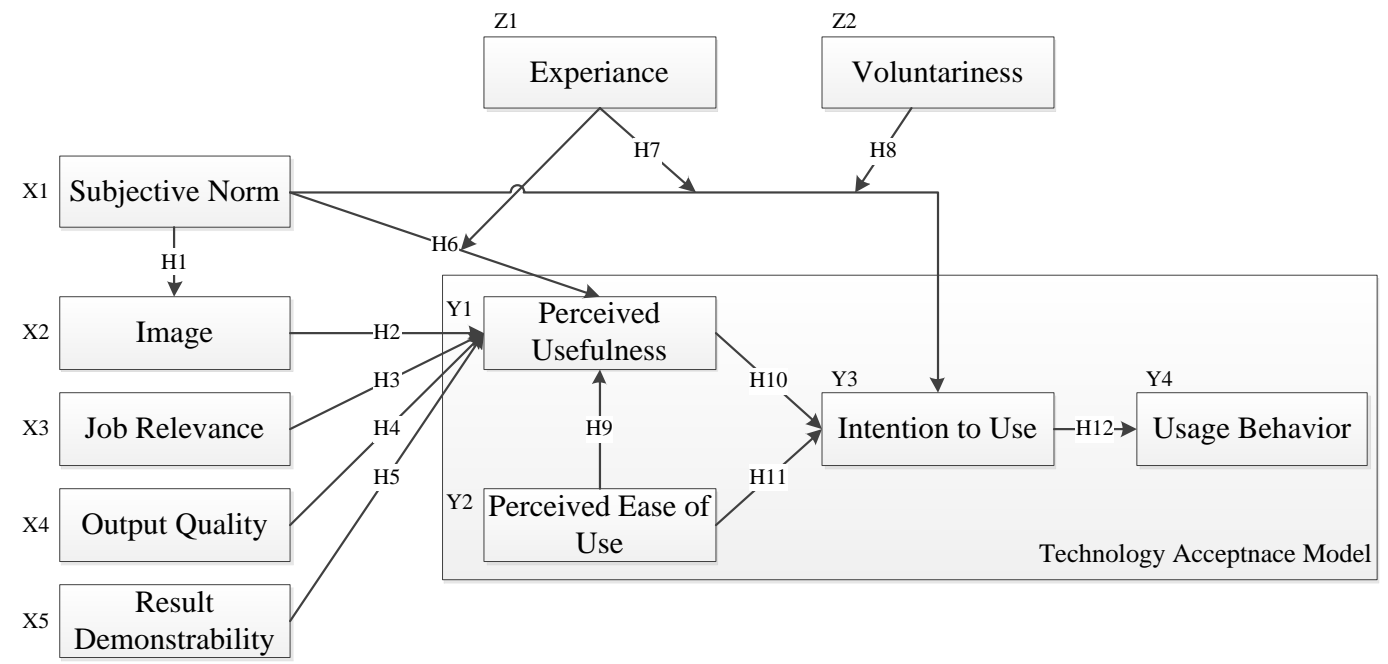

Figure 1. Model Technology Acceptance Model (TAM) 2

\section{METHOD}

\section{A. Technology Acceptance Model 2 (TAM 2)}

The TAM 2 (Technology Acceptance Model 2) is an expansion model developed by Venkatesh and Davis. TAM 2 focuses on factors in the form of determinants of perceptions regarding the benefits and use of technology [7].

In TAM 2 (Technology Acceptance Model 2), it is known that there are eleven (11) constructs, as shown in Figure 1.

1. Perceived ease of use [8] is defined as a level in which a person believes that computer can be easily understood.

2. Experience is defined as a variable that distinguishes between experienced and unexperienced users, which significantly affect in determining perceived usefulness and the behavioral intention to use technology.

3. Voluntariness is a variable which determines to affect subjective norms in behavioral intention to use technology.

4. Subjective norm is a perception (image) or a view of the beliefs of others which affect the behavioral intention to use.
5. Image is the perception of technology which can increase user status which directly affects the perceived usefulness of technology of which level is affected by subjective norms.

6. Job relevance is a user perception variable that technology can help their work specifically (perceived usefulness).

7. Output quality is related to the level of user trust that the result of technology can be useful to help their work (perceived usefulness).

8. Result of demonstrability is a variable that technology can provide perceived usefulness.

9. Perceived usefulness is defined as a measure in which the use of technology is believed to benefit the users.

10. User behavior indicates that Attitude Toward Using in TAM (Technology Acceptance Model) is conceptualized as an attitude towards the use of a system in the form of acceptance or rejection as a result of someone using technology in their work.

11. Intention to use is the tendency to continue using technology [9].

12. Behavior is a real condition of system usage [9]. In the context of the use of information technology system, behavior is conceptualized in actual use, a form of 
measurement of the frequency and duration of use of technology.

\section{B. Cloud Computing}

Cloud computing is a technology approach that aims to increase the capacity and capability of Information Technology (IT) networks by focusing on data storage and processing [10]. It allows users to access applications without installing and increasing access to personal information via the Internet [11]. In addition, cloud computing has led to reduced costs of building IT infrastructure, and in acquiring new resources. Cloud computing services benefit from multitenant architecture by maintaining one application.

\section{Microsoft Office 365}

Microsoft Office 365 is a service product from Microsoft, as part of a Microsoft Office product that aims to provide all the convenience of users in accessing information flexibly wherever and whenever. Even users can save their work in the cloud and can also be shared with other users. The Office 365 applications are similar to social media among the office 365 users and work on tasks simultaneously.

\section{Sampling}

According to [12], sample is part of the number and characteristics possessed by the population. If the number of subjects is large, the sample can be taken between 10$15 \%$ or $20-55 \%$ or more depending on the ability of the researcher. If the population is large, the researcher is not likely to learn all that exists in the population; this is because of limitations so the researcher can use samples taken from the population. Thus, the sample taken from the population must be truly representative. To determine the number of samples to be used by the researcher, the Slovin formula taking $10 \%$ as the error rate can be calculated as follows.

$$
n=\frac{N}{N e^{2}+1}
$$

In which $\mathrm{n}=$ sample size, $\mathrm{N}=$ population size (obtained from total active employees), $\mathrm{c}=$ percentage of tolerable sampling error [13].

\section{E. Validity and Reliability Tests}

Validity and reliability tests are conducted to show to which extent a measuring device can measures and show to which extent a measuring device can be trusted or is reliable. The following formula is used for validity analysis.

$$
\mathrm{R}=\frac{n \sum X Y-\left(\sum X\right)\left(\sum Y\right)}{\left.\sqrt{(n} \Sigma(X)^{2}\right)-\left(\sum X\right)^{2}\left(n \sum(Y)^{2}-\left(\sum Y\right)^{2}\right)}
$$

In which:

$\mathrm{R}=$ validity coefficient

$\mathrm{N}=$ number of subjects

$\mathrm{X}=$ comparative value

$\mathrm{Y}=$ value of instrument of which validity to be calculated

The formula to determine reliability is as follows.

$$
\alpha=\frac{k}{k-1}\left(1-\frac{\sum s j^{2}}{s x^{2}}\right)
$$

In which:

$\mathrm{K}=$ number of question instruments

$\sum \mathrm{sj}^{2}=$ number of variance on each instrument

$\mathrm{sx}^{2}=$ variance of total instrument

\section{F. Correlation and Regression Analysis}

Regression is basically the study of interdependence between dependent variable and one or more independent variables with the aim of estimating or predicting the population average or the average value of the dependent variable based on the value of the known independent variable.

\begin{tabular}{|c|c|c|}
\hline Indicators & Correlation between Item and Total Score & Notes \\
\hline $\mathbf{X 1 . 1}$ & $.914 * *$ & Valid \\
\hline $\mathbf{X} 1.2$ & $.889 * *$ & Valid \\
\hline $\mathbf{X} 2.1$ & $.813^{* *}$ & Valid \\
\hline $\mathbf{X} 2.2$ & $.825 * *$ & Valid \\
\hline $\mathbf{X} 2.3$ & $.915 * *$ & Valid \\
\hline X3.1 & $.941 * *$ & Valid \\
\hline X3.2 & $.935 * *$ & Valid \\
\hline X4.1 & $.941 * *$ & Valid \\
\hline $\mathbf{X} 4.2$ & $.935^{* *}$ & Valid \\
\hline $\mathbf{X 5 . 1}$ & $.716^{* *}$ & Valid \\
\hline $\mathbf{X} 5.2$ & $.789 * *$ & Valid \\
\hline X5.3 & $.874^{* *}$ & Valid \\
\hline X5.4 & $.753^{* *}$ & Valid \\
\hline Y1.1 & $.880 * *$ & Valid \\
\hline Y1.2 & $.859 * *$ & Valid \\
\hline Y1.3 & $.769 * *$ & Valid \\
\hline Y2.1 & $.797 * *$ & Valid \\
\hline Y2.2 & $.749 * *$ & Valid \\
\hline Y 2.3 & $.834 * *$ & Valid \\
\hline Y 2.4 & $.810 * *$ & Valid \\
\hline Y3.1 & $.932 * *$ & Valid \\
\hline Y3.2 & $.967^{* *}$ & Valid \\
\hline Y4.1 & $.825^{* *}$ & Valid \\
\hline Y4.2 & $.825^{* *}$ & Valid \\
\hline Z1.1 & $.932 * *$ & Valid \\
\hline Z1.2 & $.893 * *$ & Valid \\
\hline Z2.1 & $.835^{* *}$ & Valid \\
\hline Z2.2 & $.709 * *$ & Valid \\
\hline Z2.3 & $.665^{* *}$ & Valid \\
\hline
\end{tabular}

TABLE 1.

VALIDITY TEST SCORE 


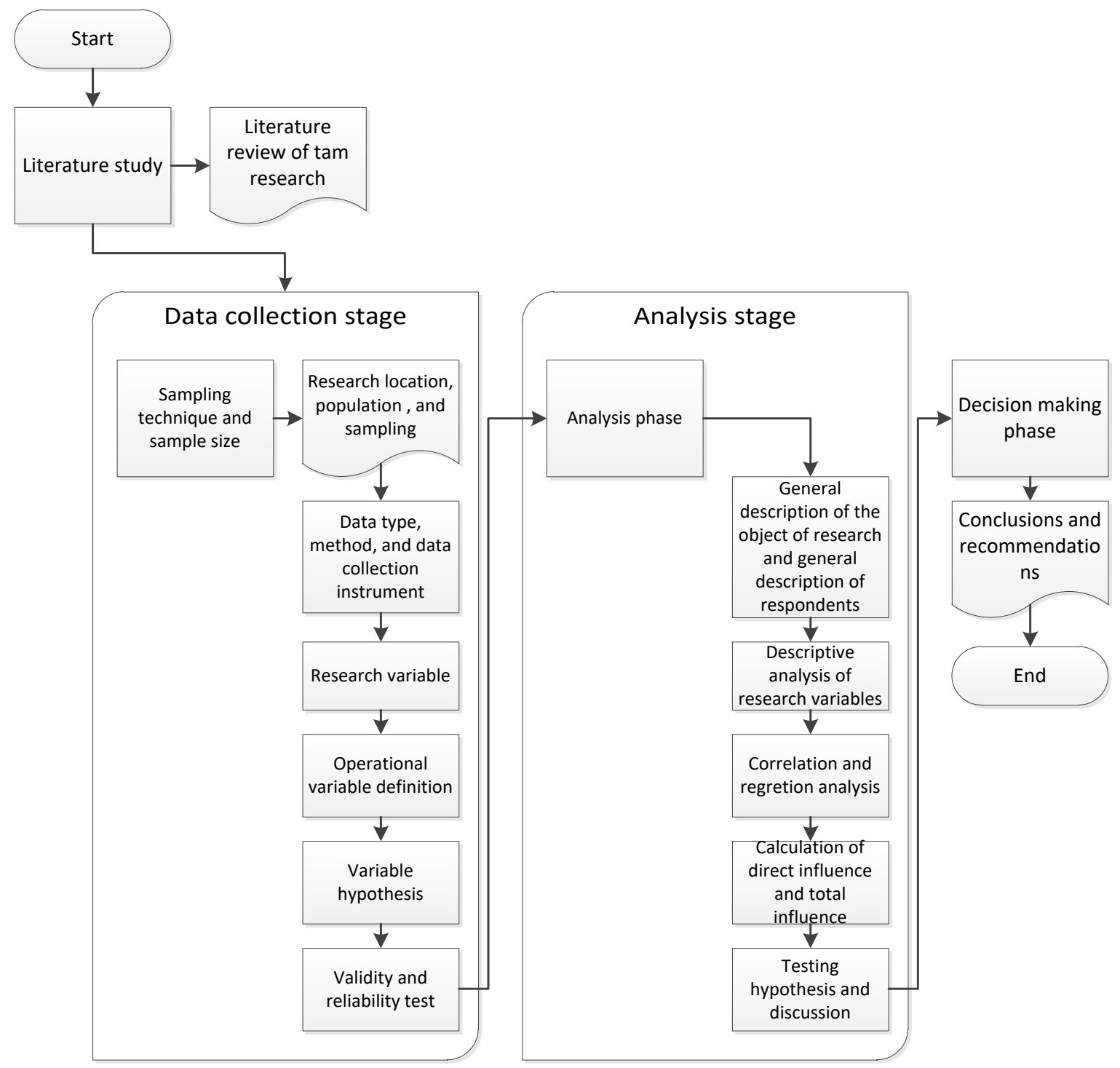

Figure 2. Research Methodology

This step serves to determine $\mathrm{H} 0$ and $\mathrm{H} 1$ in the study with the aim of examining population characteristics based on information from sample. Correlation analysis indicates the degree of relationship between two variables without regard to which variables become variables. Therefore, the correlation relationship has not been interpreted as causation [14].

\section{Methodology}

According to Figure 2, the first step (1) is the preliminary stage, type of research used and supporting data needed by the researcher. The second step (2) consists of several steps, such as the data collection, the researcher determined the object to be studied then calculate the population and samples, and determine the technique and size of the sampling. The researcher must also determine the type of data, methods, and instruments of data collection to be used. The researcher determined the research variable based on the TAM 2 method (Technology Acceptance Model), and defined the operational variables based on the questionnaire which had been distributed to 90 correspondents, which was tabulated using the SPSS 23 and Excel 2016.

After data tabulation, the researcher re-tested the data in terms of validity and reliability. The third step (3) is in the analysis stage which consists of a general description of cloud computing based applications, a general description of respondents, such as users using the application. The result of the tabulation was used to test the descriptive analysis of the research, the correlation and regression, to calculate the direct and indirect effects described using path diagram based on the regression, and to test the preset hypotheses.

The last step (4) is the decision-making stage which produced conclusions and suggestions based on the result. 
The $1^{\text {st }}$ International Conference on Business and Management of Technology (IConBMT)

August 3rd 2019, Institut Teknologi Sepuluh Nopember, Surabaya, Indonesia

\section{RESULTS AND DISCUSSION}

\section{A. Research Variabel}

Variables in this study consist of dependent and independent variables. The independent variables are:

1) Subjective Norm $(X 1)$

Indicator questions:

1. My colleagues influence to use the Office 365 application (X1.1);

2. My boss influences to use the Office 365 application (X1.2).

2) Image (X2)

Indicator questions:

1. I perform better using the Office 365 compared to other applications (X2.1);

2. I feel prioritized using the Office 365 application (X2.2);

3. Using the Office 365 application increase my social status (X2.3).

3) Job Relevance (X3)

Indicator questions:

1. Using the Office 365 is important for work (X3.1);

2. In terms information presentation, the Office 365 help my work (X3.2).

4) Output Quality (X4)

Indicator questions:

1. Information presented from using the Office 365 is accurate (X4.1);

2. The Office 365 application is of good quality in presenting information (X4.2).

5) Result Demonstrability (X5)

Indicator questions:

1. I recommend other to use the Office 365 (X5.1);

2. I do not mind explaining about the Office 365 application to others (X5.2);

3. Results of using the Office 365 application bring benefits (X5.3);

4. I do not find it difficult to explain about the Office 365 application to others (X5.6).

The dependent variables are:

1) Perceived usefulness (Y1)

Indicator questions:

1. The Office 365 application helps me work faster (Y1.1);

2. The Office 365 application helps me work effectively (Y1.2);

3. The Office 365 application meets the information needs requested by users (Y1.3).

2) Perceived Ease Of Use (Y2)

Indicator questions:

1. The Office 365 application is easy to learn (Y2.1);

2. The Office 365 application is easy to use (Y2.2);

3. The Office 365 application is easy to understand (Y2.3);

4. There is information on how to operate the Office 365 application (Y2.4).
3) Intention To Use (Y3)

Indicator questions:

1. I am interested in using the Office 365 application (Y3.1);

2. I will use the Office 365 application for my daily work (Y3.2).

4) Usage Behavior (Y4)

Indicator questions:

1. I always use the Office 365 application for my daily work (Y4.1);

2. use the Office 365 application better than other applications (Y4.2).

The moderating variables are:

1) Experience $(\mathrm{Z} 1)$

Indicator questions:

1. I am experienced in using the Office 365 application (Z1.1);

2. I have an interesting experience in using the Office 365 application (Z1.2).

2) Voluntariness (Z2)

Indicator questions:

1. I voluntarily use the Office 365 application (Z2.1);

2. My boss does not require to use the Office 365 application (Z2.2);

3. My work does not require to use the Office 365 application (Z2.3).

The result of the validity test is presented in Table 1.

One asterisk $(*)$ means a significant correlation to the significance value (2-tailed) of 0.05 at the level of $5 \%$ and two asterisks $(* *)$ mean a very significant correlation to the significance value (2 -tailed) of 0.01 at the level of $1 \%$. If the correlation is significant at $1 \%$, it is definitely also significant at the 5\% level; but if it is significant at $5 \%$, it is not necessarily significant at the $1 \%$ level [15]. The relationship in the table above is significant because the significance value is smaller than 0.05 [15]. Significant correlation or chance of alpha error is given the symbol $\mathrm{p}$ (probability of Alpha Error). Chances of error is written as "sig" on the SPSS program output.

\section{B. Hypothesis of Variables}

The hypotheses of the cloud computing-based application object were taken from the relationship between the dependent and independent variables, and are presented as follows:

H1 = Subjective norm positively affects image of cloud computing application;

$\mathrm{H} 2$ = Image positively affects perceived usefulness of cloud computing application;

$\mathrm{H} 3$ = Job relevance positively affects perceived usefulness of cloud computing application;

$\mathrm{H} 4$ = Output quality positively affects perceived usefulness of cloud computing application;

H5 = Result demonstrability positively affects perceived usefulness of cloud computing application; 
H6 = Subjective norm moderated by experience in using application positively affects perceived usefulness of cloud computing application;

H7 = Subjective norm moderated by experience in using application positively affects intention to use of cloud computing application;

$\mathrm{H} 8$ = Subjective norm moderated by voluntariness in using application positively affects intention to use of cloud computing application;

H9 = Perceived ease of use positively affects intention to use of cloud computing application;

$\mathrm{H} 10=$ Perceived usefulness positively affects intention to use of cloud computing application;

H11 = Perceived ease of use positively affects intention to use of cloud computing application;

H12 = Intention to use positively affects usage behavior of cloud computing application;

TABLE 2.

SCORE OF RELIABILITY TEST

\begin{tabular}{lccc}
\hline \hline \multicolumn{1}{c}{ Indicators } & $\begin{array}{c}\text { Number of } \\
\text { items }\end{array}$ & $\begin{array}{c}\text { Cronbach's } \\
\text { Alpha }\end{array}$ & Note \\
\hline Subjective norm & 2 & .817 & Reliable \\
Image & 3 & .827 & Reliable \\
Job relevance & 2 & .877 & Reliable \\
Output quality & 2 & .493 & Reliable \\
Result demonstrability & 4 & .862 & Reliable \\
Perceived usefulness & 3 & .869 & Reliable \\
Perceived ease of use & 4 & .881 & Reliable \\
Intention to use & 2 & .921 & Reliable \\
Usage behavior & 2 & .595 & Reliable \\
Experience & 2 & .847 & Reliable \\
Voluntariness & 3 & .693 & Reliable \\
\hline \hline
\end{tabular}

TABLE 3.

SCORE OF RELIABILITY TEST

\begin{tabular}{cccc}
\hline \hline No & $\begin{array}{c}\text { Relationship among Variables } \\
\text { (Path Diagram) }\end{array}$ & $\begin{array}{c}\text { Correlation } \\
\text { Value }\end{array}$ & Category \\
\hline 1. & $\mathrm{X} 1 \rightarrow \mathrm{X} 2$ & $0,446^{* *}$ & Significant \\
2. & $\mathrm{X} 2 \rightarrow \mathrm{Y} 1$ & $0,412^{* *}$ & Significant \\
3. & $\mathrm{X} 3 \rightarrow \mathrm{Y} 1$ & $0,509^{* *}$ & Significant \\
4. & $\mathrm{X} 4 \rightarrow \mathrm{Y} 1$ & $0,571^{* *}$ & Significant \\
5. & $\mathrm{X} 5 \rightarrow \mathrm{Y} 1$ & $0,545^{* *}$ & Significant \\
6. & $\mathrm{Z} 1 \rightarrow \mathrm{Y} 1$ & $0,315^{* *}$ & Significant \\
7. & $\mathrm{Z} 1 \rightarrow \mathrm{Y} 3$ & $0,285^{* *}$ & Significant \\
8. & $\mathrm{Z} 2 \rightarrow \mathrm{Y} 3$ & $0,341^{* *}$ & Significant \\
9. & $\mathrm{Y} 2 \rightarrow \mathrm{Y} 1$ & $0,333^{* *}$ & Significant \\
10. & $\mathrm{Y} 1 \rightarrow \mathrm{Y} 3$ & $0,479^{* *}$ & Significant \\
11. & $\mathrm{Y} 2 \rightarrow \mathrm{Y} 3$ & $0,525^{* *}$ & Significant \\
12. & $\mathrm{Y} 3 \rightarrow \mathrm{Y} 4$ & $0,438^{* *}$ & Significant \\
\hline \hline Notes: & & & \\
$* *$ Correlation is significant at the 0.05 level $(2-$ tailed). & \\
\hline
\end{tabular}

\section{Reliability Test}

The result of reliability test can be seen in Table 2 .

\section{Correlation Test}

The result of correlation test can be seen in Table 3 . From Table 3, it can be seen that one asterisk (*) means a significant correlation to the significance value (2-tailed) of 0.05 at the level of $5 \%$ and two asterisks (**) mean a very significant correlation to the significance value (2-tailed) of 0.01 at the level of $1 \%$. If the correlation is significant at $1 \%$, it is definitely also significant at the $5 \%$ level; but if it is significant at $5 \%$, it is not necessarily significant at the $1 \%$ level [15]. If there is not any either one (*) or two (**) asterisks, the correlation between correlation is weak. The relationship in Table 3 is significant because the significance value is smaller than 0.05 [15].

\section{E. Regression Test}

The result of regression test can be seen in Table 4 .

The following is the description regarding the hypothesis testing presented in Table 4:

1. $\mathrm{H} 1=$ Subjective norm positively affects image of cloud computing application with a value of 4,311 and significance value of 0,000 , below 0,05 which means that the hypothesis is accepted;

2. $\mathrm{H}_{2}=$ Image positively affects perceived usefulness of cloud computing application with a value of 2,940 and significance value of 0,004 , below 0,05 which means that the hypothesis is accepted;

3. $\mathrm{H} 3=$ Job relevance positively affects perceived usefulness of cloud computing application with a value of 5,640 and significance value of 0,004, below 0,05 which means that the hypothesis is accepted;

4. $\mathrm{H} 4=$ Output quality positively affects perceived usefulness of cloud computing application with a value of 7,855 and significance value of 0,000 , below 0,05 which means that the hypothesis is accepted;

5. $\mathrm{H} 5=$ Result demonstrability positively affects perceived usefulness of cloud computing application with a value of 6,068 and significance value of 0,000 , below 0,05 which means that the hypothesis is accepted;

6. H6 = Subjective norm moderated by experience in using application positively affects perceived usefulness of cloud computing application with a value of 2,589 and significance value of 0,011 , below 0,05 which means that the hypothesis is accepted;

7. $\mathrm{H7}=$ Subjective norm moderated by experience in using application positively affects intention to use of cloud computing application with a value of 2,555 and significance value of 0,012 , below 0,05 which means that the hypothesis is accepted;

8. $\mathrm{H} 8=$ Subjective norm moderated by voluntariness in using application positively affects intention to use of cloud computing application with a value of 3,404 and 
significance value of 0,000 , below 0,05 which means that the hypothesis is accepted;

9. $\mathrm{H} 9=$ Perceived ease of use positively affects intention to use of cloud computing application with a value of 2,135 and significance value of 0,036 , below 0,05 which means that the hypothesis is accepted;

10. $\mathrm{H} 10=$ Perceived usefulness positively affects intention to use of cloud computing application with a value of 4,241 and significance value of 0,000 , below 0,05 which means that the hypothesis is accepted;

11. H11 = Perceived ease of use positively affects intention to use of cloud computing application with a value of 6,206 and significance value of 0,000 , below 0,05 which means that the hypothesis is accepted;

12. H12 = Intention to use positively affects usage behavior of cloud computing application with a value of 4,672 and significance value of 0,000 , below 0,05 which means that the hypothesis is accepted.

\section{CONCLUSION}

Based on the analysis regarding the acceptance of the cloud computing-based application in the banking industry in Indonesia with the technology acceptance model 2 (TAM 2), it can be concluded that:

1. There are eleven (11) aspects to be considered in measuring the acceptance of the cloud computing-based application, namely subjective norm, image, job relevance, output quality, result demonstrability, perceived usefulness, perceived ease of use, intention to use, usage behavior, experience, voluntariness;
2. The highest value of variable relationship is between quality outcome (X4) and perceived usefulness (Y1), with the regression value of $41.2 \%$. This value is considered to be the most influential in measuring the acceptance of cloud computing application in the banking industry. It proves that the user is benefited by the output quality the application. The better the output quality of the application, the more useful the application is. Furthermore, another high value of variable relationship is between perceived ease of use (Y2) and intention to use (Y3). It proves that users are interested in using an application if they consider that the application is easy to use. Users are comfortable using an application if the features of the application are easy to understand and learn. The lowest value of variable relationship is between perceived ease of use (Y2) and perceived usefulness (Y1) of 4.9\%. It shows that easiness in using the Office 365 application does not affect the perceived usefulness of using the application. The easier the application is not necessarily as useful as other applications. Relationship between experience (Z1) with perceived usefulness (Y1) and experience (Z1) with intention to use (Y3) also obtain low value of 7.1 and 6.9 , respectively. It indicates that experience does not necessarily affect the acceptance of new technology. Even if the user does not have any experience using a similar application, many employees are interested in using a new application if they feel that the application provides benefits for their work;

TABLE 4.

SCORE OF REGRESSION TEST

\begin{tabular}{|c|c|c|c|c|c|}
\hline HYPOTHESIS & DESCRIPTION & $\begin{array}{c}\mathbf{R} \\
\text { Square }\end{array}$ & Value & Sig & CATEGORY \\
\hline H1 & Subjective norm positively affects image of cloud computing application & 0,174 & 4,311 & ,000 & Accepted \\
\hline $\mathrm{H} 2$ & Image positively affects perceived usefulness of cloud computing application & 0,089 & 2,940 & ,004 & Accepted \\
\hline $\mathrm{H} 3$ & Job relevance positively affects perceived usefulness of cloud computing application & 0,265 & 5,640 & ,000 & Accepted \\
\hline $\mathrm{H} 4$ & Output quality positively affects perceived usefulness of cloud computing application & 0,412 & 7,855 & ,000 & Accepted \\
\hline H5 & $\begin{array}{l}\text { Result demonstrability positively affects perceived usefulness of cloud computing } \\
\text { application }\end{array}$ & 0,295 & 6,068 & ,000 & Accepted \\
\hline H6 & $\begin{array}{l}\text { Subjective norm moderated by experience in using application positively affects } \\
\text { perceived usefulness of cloud computing application }\end{array}$ & 0,071 & 2,589 &, 011 & Accepted \\
\hline $\mathrm{H} 7$ & $\begin{array}{l}\text { Subjective norm moderated by experience in using application positively affects } \\
\text { intention to use of cloud computing application }\end{array}$ & 0,069 & 2,555 & ,012 & Accepted \\
\hline $\mathrm{H} 8$ & $\begin{array}{l}\text { Subjective norm moderated by voluntariness in using application positively affects } \\
\text { intention to use of cloud computing application }\end{array}$ & 0,116 & 3,404 & ,000 & Accepted \\
\hline H9 & $\begin{array}{l}\text { Perceived ease of use positively affects intention to use of cloud computing } \\
\text { application }\end{array}$ & 0,049 & 2,135 & ,036 & Accepted \\
\hline H10 & Perceived usefulness positively affects intention to use of cloud computing application & 0,170 & 4,241 & ,000 & Accepted \\
\hline H11 & $\begin{array}{l}\text { Perceived ease of use positively affects intention to use of cloud computing } \\
\text { application }\end{array}$ & 0,304 & 6,206 & ,000 & Accepted \\
\hline H12 & Intention to use positively affects usage behavior of cloud computing application & 0,199 & 4,672 & ,000 & Accepted \\
\hline
\end{tabular}


3. Table $\mathbf{5}$ is the result of descriptive analysis taken from the highest value and processed using excel and SPSS 23. The highest value of frequency distribution is job relevance (X3) and statement X3.2 of 3.27. It can be concluded that the Office 365 application is closely related to daily work of users. The lowest value is experience (Z1) and statement Z1.1, of 2.9. It can be concluded that users do not necessarily need experience of using similar applications to be able to operate the Office 365 application;

TABLE 5.

DESCRIPTIVE ANALYSIS

\begin{tabular}{clcc}
\hline \hline No & \multicolumn{1}{c}{$\begin{array}{c}\text { Variable Frequency } \\
\text { Distribution }\end{array}$} & Indikator & $\begin{array}{c}\text { Frequency } \\
\text { Distribution Test }\end{array}$ \\
\hline 1 & Subjective norm $(\mathrm{X} 1)$ & $\mathrm{X} 1.2$ & 3,05 \\
2 & Image (X2) & $\mathrm{X} 2.2$ & 2,96 \\
3 & Job relevance (X3) & $\mathrm{X} 3.2$ & 3,27 \\
4 & Output quality (X4) & $\mathrm{X} 4.1$ & 3,11 \\
5 & Result demonstrability (X5) & $\mathrm{X} 5.2$ & 2,95 \\
6 & Perceived usefulness (Y1) & $\mathrm{Y} 1.1$ & 3,16 \\
7 & Perceived ease of use (Y2) & $\mathrm{Y} 2.1$, & 3,08 \\
& & $\mathrm{Y} 2.2$ & \\
8 & Intention to use (Y3) & $\mathrm{Y} 3.1$ & 3,13 \\
9 & Usage behavior $(\mathrm{Y} 4)$ & $\mathrm{Y} 4.2$ & 3,24 \\
10 & Experience $(\mathrm{Z} 1)$ & $\mathrm{Z} 1.1$ & 2,9 \\
11 & Voluntariness $(\mathrm{Z} 2)$ & $\mathrm{Z} 2.1$ & 3,25 \\
\hline \hline
\end{tabular}

4. All the independent variables positively or significantly affect the dependent variables;

5. The suggestions provided for this study are:

- The company should not hesitate to implement new technology within the company because based on the result experience in using similar applications obtain the smallest value compared to other variables. On the other hand, new technology must be able to provide good quality results to obtain the maximum benefit and user friendly display, so that users are increasingly interested in using the application;
- Future study should expand the object and place of study instead of observing one bank in Surabaya and Bali, so that more data can be obtained in order to obtain increasingly complex and detailed results.

\section{REFERENCES}

[1] R. Buyya, C. S. Yeo, S. Venugopal, J. Broberg, and I. Brandic, "Cloud computing and emerging IT platforms: Vision, hype, and reality for delivering computing as the 5th utility," Futur. Gener. Comput. Syst., vol. 25, no. 6, pp. 599-616, 2009.

[2] D. Kondo, A. A. Chien, and H. Casanova, "Scheduling task parallel applications for rapid turnaround on enterprise desktop grids," J. Grid Comput., vol. 5, no. 4, pp. 379-405, 2007.

[3] P. F. Wu, "User acceptance of emergency alert technology: A case study," in Proceedings of the 6th International ISCRAM Conference, 2009.

[4] F. D. Davis, "Perceived usefulness, perceived ease of use, and user acceptance of information technology," MIS Q. Manag. Inf. Syst., vol. 13, no. 3, pp. 319-339, 1989.

[5] F. D. Davis, R. P. Bagozzi, and P. R. Warshaw, "User acceptance of computer technology: A comparison of two theoritical models," Manage. Sci., vol. 35, no. 8, pp. 982-1003, 1989.

[6] A. K. Yarbrough and T. B. Smith, "Technology acceptance among physicians: a new take on TAM.," Med. Care Res. Rev., vol. 64, no. 6, pp. 650-72, 2007.

[7] L.-C. Yu, J. Wang, K. R. Lai, and X. Zhang, "Refining word embeddings using intensity scores for sentiment analysis," IEEE/ACM Trans. Audio, Speech, Lang. Process., vol. 26, no. 3, pp. 671-681, 2018.

[8] F. N. Nasution, "Penggunaan Teknologi Informasi Berdasarkan Aspek Perilaku (Behavioral Aspect)," Universitas Sumatra Utara, 2004.

[9] A. Wibowo, "Kajian tentang perilaku pengguna sistem informasi dengan pendekatan Technology Acceptance Model (TAM)," in Prosiding Konferensi Nasional Sistem Informasi 2008 (KNSI 2008), 2008.

[10] P. Mell and T. Grance, "SP 800-145, The NIST Definition of Cloud Computing," Gaithersburg, Maryland, 2011.

[11] M. Armbrust et al., "A view of cloud computing," Commun. ACM, vol. 53, no. 4, p. 50, Apr. 2010.

[12] Sugiyono, Statistika untuk Penelitian. Bandung: Alfabeta, 2005.

[13] I. Agung, Panduan Penelitian Tindakan Kelas bagi Guru. Jakarta, Indonesia: Bestari Buana Murni, 2012.

[14] A. Pratisto, Statistik Menjadi Lebih Mudah Dengan SPSS 17. Jakarta, Indonesia: Elex Media Koputindo, 2009.

[15] M. Nisfiannoor, Pendekatan Statistika Modern Untuk Ilmu Sosial. Jakarta, Indonesia: Salemba Humanika, 2009. 